\title{
Evaluation of POST-Harvest Herbicide Applications for Seed Prevention of Glyphosate-Resistant Palmer amaranth (Amaranthus palmeri)
}

\author{
Whitney D. Crow, Lawrence E. Steckel, Robert M. Hayes, and Thomas C. Mueller*
}

Recent increases in the prevalence of glyphosate-resistant (GR) Palmer amaranth mandate that new control strategies be developed to optimize weed control and crop performance. A field study was conducted in 2012 and 2013 in Jackson, TN, and in 2013 in Knoxville, TN, to evaluate POST weed management programs applied after harvest (POST-harvest) for prevention of seed production from GR Palmer amaranth and to evaluate herbicide carryover to winter wheat. Treatments were applied POST-harvest to corn stubble, with three applications followed by a PRE herbicide applied at wheat planting. Paraquat alone or mixed with $S$-metolachlor controlled $91 \%$ of existing Palmer amaranth $14 \mathrm{~d}$ after treatment but did not control regrowth. Paraquat tank-mixed with a residual herbicide of metribuzin, pyroxasulfone, saflufenacil, flumioxazin, pyroxasulfone plus flumioxazin, or pyroxasulfone plus fluthiacet improved control of regrowth or new emergence compared with paraquat alone. All residual herbicide treatments provided similar GR Palmer amaranth control.

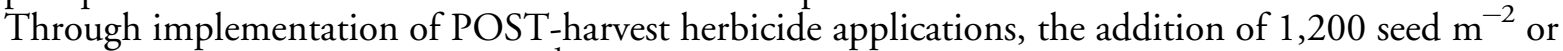
approximately 12 million seed ha ${ }^{-1}$ to the soil seedbank was prevented. Overall, the addition of a residual herbicide provided only 4 to $7 \%$ more GR Palmer amaranth control than paraquat alone. Wheat injury was evident $(<10 \%)$ in 2012 from the PRE applications, but not in 2013. Wheat grain yield was not adversely affected by any herbicide application.

Nomenclature: Pyroxasulfone, 5-(difluoromethoxy)-1-methyl-3-(trifluoromethyl)pyrazol-4ylmethyl 4,5-dihydro-5,5-dimethyl-1,2-oxazol-3-yl sulfone; Palmer amaranth, Amaranthus palmeri S. Wats; corn, Zea mays L.; wheat, Triticum aestivum L.

Key words: Glyphosate resistance, herbicide resistance, weed control.

\begin{abstract}
Aumentos recientes en la prevalencia de Amaranthus palmeri resistente a glyphosate (GR) requiere que nuevas estrategias de control sean desarrolladas para optimizar el control de malezas y el desempeño de los cultivos. Se realizó un estudio de campo en 2012 y 2013, en Jackson, Tennessee, y en 2013 en Knoxville, Tennessee, para evaluar programas de manejo de malezas POST aplicados después de la cosecha (POST-cosecha) para la prevención de la producción de semilla de $A$. palmeri GR y para evaluar la residualidad de los herbicidas durante el trigo de invierno. Los tratamientos fueron aplicados POST-cosecha a campos después de la cosecha del maíz, con tres aplicaciones seguidas por un herbicida PRE aplicado al momento de la siembra del trigo. Paraquat solo o en mezcla con $S$-metolachlor controló $91 \%$ del $A$. palmeri existente $14 \mathrm{~d}$ después del tratamiento, pero no controló el rebrote de la maleza. La mezcla en tanque de paraquat con un herbicida residual ya sea metribuzin, pyroxasulfone, saflufenacil, flumioxazin, pyroxasulfone más flumioxazin, o pyroxasulfone más fluthiacet mejoró el control de rebrotes o nueva emergencia de plántulas al compararse con paraquat solo. Mediante la implementación de aplicaciones de herbicidas POST-cosecha se previno la adición al banco de semillas de 1,200 semillas $\mathrm{m}^{-2} \mathrm{o}$ aproximadamente 12 millones de semillas ha ${ }^{-1}$. En general, la adición de un herbicida residual brindó solamente $4 \mathrm{a}$ $7 \%$ más control de $A$. palmeri GR que paraquat solo. El daño al trigo fue vidente $(<10 \%)$ con las aplicaciones PRE en 2012, pero no en 2013. El rendimiento de grano del trigo no fue afectado adversamente por ninguna de las aplicaciones de herbicidas.
\end{abstract}

\footnotetext{
DOI: 10.1614/WT-D-14-00146.1

* First, second, and third authors: Graduate Research Assistant, Professor, Professor, Department of Plant Sciences, University of Tennessee, 605 Airways Boulevard, Jackson, TN 38301; fourth author: Professor, Department of Plant Sciences, University of Tennessee, 2431 Joe Johnson Drive, Knoxville, TN 37996. Corresponding author's E-mail: lsteckel@utk.edu
}

Weed management in field corn production systems in Tennessee is largely dependent on herbicide programs to control problematic weed species. To slow the evolution of further herbicide resistance in Palmer amaranth, it is important to incorporate multiple mechanisms of action into herbicide programs (Norsworthy et al. 2012). Furthermore, producers should employ year-round weed management programs and shift to programs 
with less reliance on herbicides for weed control. Therefore, POST herbicides applied after harvest (POST-harvest) for Palmer amaranth control is an important aspect of sustainable management to prevent seed production and the subsequent spread of herbicide-resistant species. Current corn production systems that solely rely on in-season herbicides are not effective for the control of late-season escapes or new plant germination (VanGessel 2001).

In areas of warm climate, the interval between corn harvest and the first killing frost is a sufficient amount of time to allow for new germination or for mechanically damaged Palmer amaranth that have survived harvest operations to reproduce, allowing for replenishment of the soil seedbank (Bagvanthiannan and Norsworthy 2012). The soil seedbank serves as a reservoir for pernicious weeds, allowing for their dispersal and future reproduction, including herbicide-resistant species (Norsworthy et al. 2012). Late-season weed escapes contribute greatly to the soil seedbank, making them a major concern for producers seeking to control weed proliferation (Bagvanthiannan and Norsworthy 2012). These late-season escapes are common in weed management programs that utilize only POST applications with no residual herbicides (VanGessel 2001). Weed species with prolific seed production provide significant seedbank replenishment. Studies have shown that the residual population may be sufficient to persist for several years after the implementation of weed management programs that are effective in controlling late-season weeds (Schweizer and Zimdahl 1984).

For species like Palmer amaranth with prolific seed production, rapid growth, and the ability to produce viable seed from plants that are $<15 \mathrm{~cm}$ in height, a late-season female plant can donate to the seedbank. Palmer amaranth seed production from plants emerging in the spring generally averages 200,000 to 600,000 seed plant $^{-1}$ (Keeley et al. 1987; Sosnoskie et al. 2014). Palmer amaranth severed near the soil line the second week of July in a standing cotton crop has been reported to grow back and produce 28,000 seed (Sosnoskie et al. 2014). There is no current documentation of Palmer amaranth seed production for plants that emerge in the late summer or fall.

Palmer amaranth at a density of 12 plants ha ${ }^{-1}$ has the potential to produce an additional 5 million seed $\mathrm{ha}^{-1}$, effectively replenishing the seedbank (Culpepper and Sosnoskie 2011). These seed may germinate from soils as early as March 1 until as late as October 1 and will typically flower between September and October (Keeley et al. 1987). Species like Palmer amaranth with biological attributes of prolific seed production, long germination window, and development of herbicide resistance should invoke a zero-tolerance seed production policy. Studies have shown that after 6 $\mathrm{yr}$ of weed-free conditions, seed populations were reduced $98 \%$ with an average of 7.7 seed $(100 \mathrm{~g})^{-1}$ of soil (Menges 1987). However, the remaining population (2\%) represented approximately 18 million seed ha ${ }^{-1}$ (Menges 1987). Such reduction in the soil seedbank is a clear indicator that maintaining zero seed production will diminish the severity of persistent weed species.

In some areas, producers can use POST-harvest tillage as an effective tool for weed management. Tillage reduces the seedbank by stimulating seed germination and killing emerged plants. However, in Tennessee, POST-harvest tillage is not always the best strategy to use because of the potential for erosion on the rolling topography (NRCS 2007). In 2012, 94\% of corn hectares were planted in notillage production systems or some form of conservative tillage, whereas only $6 \%$ was conventional tillage (USDA 2013). Thus, herbicidal control is the main driver in managing Palmer amaranth POSTharvest and preventing high-volume seed production in no-tillage systems (Buhler 1995; Coffman and Frank 1991; Koskinen and McWhorter 1986; Nowak 1983). Jones and Medd (2005) observed that late-season herbicide applications to prevent seed production were very effective in reducing seed densities.

Weed seed rain is the reproduction or dispersal of seed from weed species that contribute to the replenishment of the soil seedbank (Bagvanthiannan and Norsworthy 2012). By implementing POSTharvest weed management practices, weed seed rain and density are both effectively reduced (Brewer and Oliver 2007; Clay and Griffin 2000; Taylor and Oliver 1997). This decreases the probability of propagation of resistant alleles and, from an herbicide resistance management standpoint, prevents the reproduction of surviving individuals and decreases the spread of herbicide-resistant species (Norsworthy et al. 2012). This exemplifies the 
Table 1. Herbicides, rates, and manufacturers.

\begin{tabular}{llrl}
\hline Herbicide & & & \\
\cline { 1 - 2 } Trade name & Common name & Rate & \\
\cline { 1 - 2 } Gramoxone SL & Paraquat & 840 & Manufacturer \\
Sencor & Metribuzin & 263 & Syngenta Crop Protection, Greensboro, NC \\
Dual Magnum & S-metolachlor & 1070 & Bayer CropScience, Research Triangle Park, NC \\
Valor SX & Flumioxazin & 72 & Syngenta Crop Protection, Greensboro, NC \\
Sharpen & Saflufenacil & 50 & Valent BioSciences Corporation, Walnut Creek, CA \\
Zidua & Pyroxasulfone & BASF Corporation, Research Triangle Park, NC \\
Finesse & Chlorsulfuron & BASF Corporation, Research Triangle Park, NC \\
& Metsulfuron & DuPont Crop Protection, Wilmington, DE \\
Axiom & Flufenacet methyl & 79 & Bayer CropScience, Research Triangle Park, NC \\
Fierce & Metribuzin & 228 & Valent BioSciences Corporation, Walnut Creek, CA \\
Anthem & Pyroxasulfone & 57 & \\
& Flumioxazin & 70 & FMC Corporation, Philadelphia, PA \\
\hline
\end{tabular}

primary objective of POST-harvest weed management practices, which is to prevent seed production by enforcing a zero-tolerance seed production policy to reduce the soil seedbank and reduce the spread of problematic weed species.

The objective of this research is to evaluate POST-harvest weed management programs for the prevention of Palmer amaranth seed production following corn production systems, as well as to evaluate herbicide injury, or carryover, to fall-seeded winter wheat.

\section{Materials and Methods}

Field experiments were conducted at the West Tennessee Research and Education Center (WTREC) in Jackson, TN $(35.632227 \mathrm{~N}$, $88.857739 \mathrm{~W})$, in 2012 and at another location at WTREC in 2013 and at the Holsten Research Center in Knoxville, TN (35.974659N, 83.856105W) in 2013 to evaluate POST-harvest Palmer amaranth control in corn and subsequent herbicide injury to fall-seeded, no-till winter wheat. Corn was harvested with a six-row Case IH (Racine, WI) combine in each year and location of the study. Pioneer 26R53 (Johnston, IA) wheat was planted $2 \mathrm{~cm}$ deep with a seed population of 3,000,000 seed ha ${ }^{-1}$ into standing corn stalks using a no-till drill at all locations and years. The location each test was established was free of winter annual weeds, so no herbicides other than trial treatments were applied. All other wheat management practices were conducted as directed by University of Tennessee recommendations (Raper 2014).

POST-harvest herbicides included paraquat applied alone or in combination with a residual herbicide (Table 1). All POST-harvest herbicide applications also contained non-ionic surfactant at $0.25 \%(\mathrm{v} / \mathrm{v})$. Three POST-harvest herbicide applications were followed by a PRE herbicide application of pyroxasulfone, flufenacet methyl, or chlorsulfuron plus metsulfuron methyl. Herbicide application rates are presented in Table 1. POSTharvest herbicide applications were made to Palmer amaranth that ranged in height from 6 to $50 \mathrm{~cm}$, with many of them beginning to flower but not yet producing seed, whereas PRE applications were made to no-till wheat at the time of planting. Herbicide applications were applied with a pressurized $\mathrm{CO}_{2}$ backpack sprayer calibrated to deliver 168 $\mathrm{L} \mathrm{ha}^{-1}$ using XR 110025 flat fan nozzles (TeeJet, 1801 Business Park Drive, Springfield, IL 62703) set at $186 \mathrm{kPa}$. POST-harvest herbicides were applied $5 \mathrm{~d}$ after corn harvest on August 14, 2012, and September 16, 2013, at Jackson and September 24, 2013, at Knoxville. PRE herbicides were applied at wheat planting on October 10, 2012, and October 14, 2013, at Jackson and October 17, 2013, at Knoxville.

Palmer amaranth control was evaluated at POSTharvest application timings of 7 and $14 \mathrm{~d}$ after application (DAA) using a scale of 0 (no control) to

Crow et al.: POST-harvest seed prevention • 407 
Table 2. Glyphosate-resistant Palmer amaranth control and seed counts following POST herbicide applications applied after harvest (POST-harvest). ${ }^{\mathrm{a}}$

\begin{tabular}{|c|c|c|c|c|}
\hline \multicolumn{2}{|l|}{ Herbicide treatment } & \multicolumn{2}{|c|}{ Rate } & $\frac{\text { Palmer amaranth }^{\mathrm{b}}}{\text { Seed count }^{\mathrm{d}}}$ \\
\hline & $\mathrm{g}$ ai ha ${ }^{-1}$ & 7 DAA & 14 DAA & seed $\mathrm{m}^{-2}$ \\
\hline Paraquat & 840 & $98 \mathrm{a}^{\mathrm{e}}$ & $91 \mathrm{~b}$ & $0 \mathrm{~b}$ \\
\hline Paraquat plus metribuzin & 840,263 & $99 \mathrm{a}$ & $97 \mathrm{a}$ & $0 \mathrm{~b}$ \\
\hline Paraquat plus $S$-metolachlor & $840,1,070$ & $98 \mathrm{a}$ & $97 \mathrm{a}$ & $0 \mathrm{~b}$ \\
\hline Paraquat plus $S$-metolachlor fb flufenacet, metribuzin & $840,1,070 \mathrm{fb} 228,57$ & $99 \mathrm{a}$ & $95 \mathrm{ab}$ & $0 \mathrm{~b}$ \\
\hline Paraquat plus flumioxazin & 840,72 & $98 \mathrm{a}$ & $98 \mathrm{a}$ & $0 \mathrm{~b}$ \\
\hline Paraquat plus saflufenacil & 840,50 & $99 \mathrm{a}$ & $99 \mathrm{a}$ & $0 \mathrm{~b}$ \\
\hline Paraquat plus pyroxasulfone & 840,149 & $98 \mathrm{a}$ & $98 \mathrm{a}$ & $0 \mathrm{~b}$ \\
\hline Paraquat plus flumioxazin and pyroxasulfone ${ }^{f}$ & $840,70,89$ & $99 \mathrm{a}$ & $99 \mathrm{a}$ & $0 \mathrm{~b}$ \\
\hline
\end{tabular}

${ }^{a}$ Abbreviations: fb, followed by; DAA, days after application.

${ }^{\mathrm{b}}$ Data were pooled across $2 \mathrm{yr}$ (2012 and 2013) and two locations (Jackson, TN, and Knoxville, TN).

${ }^{\mathrm{c}}$ Palmer amaranth control was evaluated 7 and $14 \mathrm{~d}$ after POST-harvest applications based on a visual scale of 0 (no control) to 100 (complete control).

${ }^{\mathrm{d}}$ Means followed by the same letter are not significantly different according to Fisher's protected LSD at $\mathrm{P} \leq 0.05$.

${ }^{\text {e }}$ Seed was collected $21 \mathrm{~d}$ after POST-harvest applications.

${ }^{\mathrm{f}}$ Pyroxasulfone premixes were evaluated only in 2013.

100 (complete control) based on visual estimates compared with the nontreated checks. Palmer amaranth seed was collected from plants in a 0.5$\mathrm{m}^{2}$ area from each plot just before wheat planting (Table 2). Seed were harvested as described by Steckel et al. (2003) using a No. C 0.21-cm round sieve (Seedburo Equipment Company, Chicago, IL) by hand threshing. Seeds were then counted 21 DAA, as outlined by Sosnoskie et al. (2014), wherein the refined seed biomass was measured and subsamples consisting of a fixed volume of Palmer amaranth seed were collected. The subsamples were also weighed and seed number quantified. Total seed numbers in the larger refined samples were then estimated using the equation

$$
S_{\text {Total }}=\left(M_{\text {Total }}\right)\left(S_{\text {Sample }}\right) / M_{\text {Sample }}
$$

where $M_{\text {Total }}$ is the total seed biomass from a given plant and $S_{\text {Sample }}$ and $M_{\text {Sample }}$ are the number of seed in and the biomass of the subsample, respectively. Germination ability of a seed sample is determined by placing 100 seed on moistened germination paper in a petri dish for $28 \mathrm{~d}$. A seedling was considered viable once a radical longer than $3 \mathrm{~mm}$ was observed.

Wheat injury from PRE herbicides was evaluated at crop emergence using a scale of 0 (no injury) to 100 (plant death) based on visual estimates of wheat phototoxicity, compared with the nontreated check. Wheat biomass was collected as fresh weights in a $0.3 \mathrm{~m}^{-2}$ area within the $1.5-\mathrm{m}$-wide treated portion of the plot. Wheat was harvested using a small-plot combine, and grain yield was adjusted to $13 \%$ moisture content.

Data were subjected to analysis of variance using the PROC MIXED procedure of SAS (ver. 9.3; SAS Institute; Cary, NC). ANOVA was used to test for significant main effects and interactions. Means were separated using Fishers protected LSD procedure at the 0.05 level of significance. Herbicide treatments were considered fixed effects in the model, whereas locations and years (environments) and replication (nested within environment), and all interactions that included these factors, were considered random effects. Designating environments random broadens the possible inference space to which the experimental results are applicable (Carmer et al. 1989). 


\section{Results and Discussion}

Glyphosate-Resistant Palmer Amaranth Control. All treatments had at least $98 \%$ control of glyphosate-resistant (GR) Palmer amaranth 7 DAA (Table 2). Paraquat alone or paraquat tankmixed with S-metolachlor provided less control than all other treatments by 14 DAA.

Although paraquat desiccated existing Palmer amaranth, regrowth occurred from larger plants $(>60 \mathrm{~cm})$, suggesting that adding a photosystem II-inhibiting or protoporphyrinogen oxidase-inhibiting herbicide to paraquat aided in controlling plant regrowth as well as preventing additional plants from emerging. In warmer climates, like the state of Tennessee, there is on average $50 \mathrm{~d}$ after corn harvest until the first frost where POSTharvest conditions are often optimal for Palmer amaranth germination, given enough rainfall. Therefore, Palmer amaranth is able to overcome a cultural weed management practice of crop rotation by producing a great amount of seed after corn harvest.

Seed Collection. Rapid buildup of viable seed in the soil seedbank is critical for resistant populations, including herbicide-resistant species. To limit longterm weed pressure from weeds like Palmer amaranth, it is vital to enforce a zero-tolerance weed seed program. Therefore, there should be no seed production from these plants, meaning that control measures should extend throughout the growing season (Norsworthy et al. 2014). All treatments prevented seed production of GR Palmer amaranth, even when weed control was not complete. Replenishment of the soil seedbank was reduced by 1,200 seed $\mathrm{m}^{-2}$, or approximately 12 million seed ha ${ }^{-1}$ (Table 2). Of these seed, $>80 \%$ came from plants that recovered from damaged inflicted by the mechanical corn harvesting equipment. Germination percentage of Palmer amaranth seed collected after corn harvest was $70 \%$. This is similar to Sosnoskie et al. (2014), who found that the average Palmer amaranth plant severed near the soil line the second week of July in a cotton crop could grow back and produce 28,000 seed per plant. Moreover, they reported there was no difference in seed germination rate $(76 \%)$ for seed recovered from Palmer amaranth plants that were severed at the soil line compared with those left undisturbed until cotton harvest. These results suggest that in corn production in the southern region of the US, Palmer amaranth severed near the soil line during corn harvest, which typically occurs in July and August, could still grow back and produce seed before first frost. These results could also have implications for other crops harvested in July and August in that region.

Wheat Injury. Treatments that did not receive a PRE herbicide had no wheat injury on the basis of visual estimates, indicating that there was no herbicide carryover from our POST-harvest applications.

Wheat phytotoxicity was only evident from PRE applications in 2012 at the Jackson location. Thus, the following results on wheat injury are exclusively for that environment. Wheat injury ranged from 5 to $10 \%$ at 12 DAA of PRE herbicides (Table 3). The physical injury symptoms were stunting and leaf necrosis. Treatments receiving a PRE application of pyroxasulfone had the greatest wheat injury $(10 \%)$ at 12 DAA, whereas chlorsulfuron plus metsulfuron methyl and flufenacet methyl plus metribuzin caused little injury $(\leq 5 \%)$. No treatment had $>4 \%$ wheat injury at $25 \mathrm{~d}$ after wheat planting.

The reason for wheat injury with those herbicide treatments for 2012 at the Jackson location could be due to more rainfall at that location that year compared with Jackson and Knoxville in 2013. From the time between herbicide application and wheat planting, $16 \mathrm{~cm}$ more rainfall fell in the Jackson location in 2012 than in 2013. Moreover, the Knoxville environment received very little rain $(1.2 \mathrm{~cm})$ during this interval compared with the 2012 Jackson environment $(38 \mathrm{~cm})$. Therefore, the authors suggest that the observed wheat injury for the 2012 Jackson environment is likely due to the amount of rainfall and herbicide uptake in October (Table 4). These results would be consistent with the pyroxasulfone label, which states that this herbicide should be applied after wheat has a $1.25-\mathrm{cm}$ sprout or injury may occur (Anonymous 2015).

In previous research, pyroxasulfone caused $<8 \%$ wheat injury with no effect on winter wheat grain yield (Hulting et al. 2012). Flufenacet methyl plus metribuzin had $<19 \%$ wheat injury in a range of 3 to $25 \mathrm{wk}$ after treatment (Koepke-Hill et al. 2011). These results were similar to the range of injury observed from the PRE herbicides in this study.

Crow et al.: POST-harvest seed prevention •

409 
Table 3. Wheat response, biomass, and grain yield following POST herbicide applications applied after harvest (POST-harvest). ${ }^{\mathrm{a} b}$

\begin{tabular}{|c|c|c|c|c|c|c|c|}
\hline \multirow{4}{*}{ Herbicide treatment } & \multirow{4}{*}{$\frac{\text { Rate }}{\text { ai ha }}$} & \multicolumn{6}{|c|}{ Wheat } \\
\hline & & \multicolumn{4}{|c|}{2012 only } & \multicolumn{2}{|c|}{2012 and 2013} \\
\hline & & \multicolumn{2}{|c|}{ Injury $^{\mathrm{c}, \mathrm{d}}$} & \multirow{2}{*}{$\frac{\text { Biomass }^{\mathrm{d}, \mathrm{e}}}{\mathrm{g} \mathrm{m}^{-2}}$} & \multirow{2}{*}{$\frac{\text { Yield }^{\mathrm{f}, \mathrm{g}}}{\mathrm{kg} \mathrm{ha}^{-1}}$} & \multirow{2}{*}{$\frac{\text { Biomass }^{\mathrm{e}, \mathrm{g}}}{\mathrm{g} \mathrm{m}^{-2}}$} & \multirow{2}{*}{$\frac{\text { Yield }^{\mathrm{f}, \mathrm{g}}}{\mathrm{kg} \mathrm{ha}^{-1}}$} \\
\hline & & $12 \mathrm{DAP}$ & 25 DAP & & & & \\
\hline Paraquat & 840 & & & $570 \mathrm{ab}$ & 3,770 & 420 & 4,830 \\
\hline Paraquat plus metribuzin & 840,263 & & & 450 abcd & 3,820 & 400 & 5,250 \\
\hline Paraquat plus $S$-metolachlor & $840,1,070$ & & & $500 \mathrm{abc}$ & 4,210 & 420 & 5,250 \\
\hline $\begin{array}{l}\text { Paraquat plus metribuzin } \mathrm{fb} \\
\text { chlorsulfuron, metsulfuron }\end{array}$ & $840,263,33,7$ & $5 \mathrm{~b}$ & $1 \mathrm{~b}$ & $240 \mathrm{e}$ & 3,600 & 300 & 4,950 \\
\hline $\begin{array}{l}\text { Paraquat plus } S \text {-metolachlor } \mathrm{fb} \\
\text { pyroxasulfone } \\
\text { Paraquat plus } S \text {-metolachlor } \mathrm{fb}\end{array}$ & $840,1,070149$ & $10 \mathrm{a}$ & $4 \mathrm{a}$ & $280 \mathrm{de}$ & 3,730 & 330 & 5,210 \\
\hline $\begin{array}{l}\text { Paraquat plus S-metolachlor fb } \\
\text { flufenacet-methyl, metribuzin }\end{array}$ & $840,1,070228,57$ & $5 \mathrm{~b}$ & $3 \mathrm{a}$ & 350 cde & 3,890 & 380 & 5,240 \\
\hline Paraquat plus flumioxazin & 840,72 & & & $390 \mathrm{bcd}$ & 3,560 & 360 & 5,220 \\
\hline Paraquat plus saflufenacil & 840,50 & & & $630 \mathrm{a}$ & 3,840 & 470 & 5,050 \\
\hline Paraquat plus pyroxasulfone & 840,149 & & & $530 \mathrm{abc}$ & 3,430 & 410 & 4,870 \\
\hline $\begin{array}{l}\text { Paraquat plus flumioxazin and } \\
\text { pyroxasulfone }\end{array}$ & $840,70,89$ & & & & & 360 & 4,910 \\
\hline $\begin{array}{l}\text { Paraquat plus pyroxasulfone and } \\
\text { fluthiacet }^{\mathrm{i}}\end{array}$ & $840,128,4$ & & & & & 580 & 5,570 \\
\hline Nontreated Check & & & & $570 \mathrm{ab}$ & 3,670 & 420 & 5,230 \\
\hline $\mathrm{P}$ values & & 0.0001 & 0.0400 & 0.0042 & 0.2579 & 0.1030 & 0.1190 \\
\hline
\end{tabular}

${ }^{a}$ Abbreviations: DAP, days after wheat planting; fb, followed by.

${ }^{\mathrm{b}}$ Data for Knoxville, TN (2013), and pooled across 2 yr (2012 and 2013) for Jackson, TN.

${ }^{\mathrm{c}}$ Wheat injury was evaluated using a scale of 0 (no injury) to 100 ( plant death) at 12 and 25 DAP.

${ }^{\mathrm{d}}$ Means followed by the same letter are not significantly different according to Fisher's protected LSD at $\mathrm{P} \leq 0.05$.

${ }^{\mathrm{e}}$ Wheat biomass collected and weighed in each plot at tillering.

${ }^{\mathrm{f}}$ Wheat yield collected from 1.5 and $9 \mathrm{~m}$ of the treated area.

${ }^{\mathrm{g}}$ Means were not statistically significant using Fisher's protected LSD at $\mathrm{P} \leq 0.05$.

${ }^{\mathrm{h}}$ Herbicide treatments that had a follow-up PRE herbicide application at wheat planting.

${ }^{i}$ Pyroxasulfone premixes were evaluated only in 2013.

Wheat Biomass. Wheat biomass ranged from 304 to $579 \mathrm{~g} \mathrm{~m}^{-2}$ and varied by environment. Differences in wheat biomass due to wheat injury were not evident (Table 3). In 2012, wheat biomass ranged from 236 to $566 \mathrm{~g} \mathrm{~m}^{-2}$. There was a trend for reduced biomass in PRE herbicide treatments (Table 3) with $\mathrm{P}=0.10$.

\section{Effect of Herbicide Application on Wheat Yield.}

There was no wheat grain yield loss because of wheat injury from either herbicide carryover or injury from the PRE herbicide applications (Table 3). Even in 2012, when wheat injury from PRE herbicides was evident, grain yield was not adversely affected.

With an increase in the prevalence of conservation tillage, weed control has become more difficult. As tillage has been reduced, reliance on herbicides
Table 4. Rainfall after PRE herbicide application to wheat in Jackson (2012 and 2013) and Knoxville, TN (2013).

\begin{tabular}{lccc}
\hline & \multicolumn{3}{c}{ Rainfall } \\
\cline { 2 - 3 } & \multicolumn{2}{c}{ Jackson, TN } & Knoxville, TN \\
\cline { 2 - 3 } Weeks after application & 2012 & 2013 & 2013 \\
\hline & \multicolumn{3}{c}{$\mathrm{cm} \mathrm{wk}^{-1}$} \\
\cline { 2 - 3 } 0 & 7.4 & 0.20 & 0.50 \\
1 & 0 & 6.25 & 0 \\
2 & 0 & 0.20 & 0 \\
3 & 12.30 & 3.90 & 0 \\
4 & 2.70 & 1.20 & 0 \\
5 & 0.20 & 0.25 & 0.20 \\
6 & 5.00 & 4.50 & 0.05 \\
7 & 3.20 & 0.50 & 0.45 \\
8 & 4.40 & & \\
9 & 0.90 & & \\
10 & 0 & & \\
\hline
\end{tabular}


for weed management has increased, presenting a new set of challenges for producers. Weed populations tend to increase in conservation tillage; thus, for species like Palmer amaranth, enforcing a zerotolerance seed production policy is vital (Price et al. 2011). The importance of controlling late-season weed escapes and subsequent seed production is critical in effectively managing the long-term soil seedbank. By controlling seed production, the spread of herbicide-resistant Palmer amaranth will decrease, preventing the replenishment of the soil seedbank and ultimately allowing for a decrease in the viable population of this problematic species.

\section{Literature Cited}

Anonymous. 2015. Supplemental Zidua herbicide label. Page 2. www.agproducts.basf.us/products/label-and-msds/ zidua-herbicide-supp-label-3.pdf. Accessed February 25, 2015

Bagavathiannan MV, Norsworthy JK (2012) Late-season seed production in arable weed communities: management implications. Weed Sci 60:325-334

Brewer CE, Oliver LR (2007) Reducing weed seed rain with lateseason glyphosate applications. Weed Technol 21:753-758

Buhler DD (1995) Influence of tillage systems on weed population dynamics and management in corn and soybean in the central USA. Crop Sci 35:1247-1258.

Carmer, SG, Nyquist WE, Walker WM (1989) Least significant differences for combined analysis of experiments with two or three-factor treatment designs. Agron J 81:665-672

Clay PA, Griffin JL (2000) Weed seed production and seedling emergence responses to late-season glyphosate applications. Weed Sci 48:481-486

Coffman CB, Frank JR (1991) Weed-crop responses to weed management systems in conservation tillage corn (Zea mays). Weed Technol 5:76-81

Culpepper SA, Sosnoskie LM (2011) Palmer amaranth management for 2011 begins now. Georgia Cotton Newsletter. The University of Georgia Cooperative Extension. http:// commodities.caes.uga.edu/fieldcrops/cotton/cnl070910.pdf. Accessed: June 13, 2014

Hulting AG, Dauer JT, Hind-Cook B, Cutis D, Koepke-Hill RM, Mallory-Smith C (2012) Management of Italian ryegrass (Lolium perenne ssp. multiflorum) in western Oregon with preemergence applications of pyroxasulfone in winter wheat. Weed Technol 26:230-235

Jones RE, Medd RW (2005) A methodology for evaluating risk and efficacy of weed management technologies. Weed Sci 53:505-514

Keeley PE, Carter CH, Thullen RM (1987) Influence of planting date on growth of Palmer amaranth (Amaranthus palmeri). Weed Sci 35:199-204
Koepke-Hill RM, Armel GR, Bradley KW, Bailey WA, Wilson HP, Hines TE (2011) Evaluation of flufenacet plus metribuzin mixtures for control of Italian ryegrass in winter wheat. Weed Technol 25:563-567

Koskinen WC, McWhorter CG (1986) Weed control in conservation tillage. J Soil Water Conserv 41:365-370

Menges RM (1987) Weed seed population dynamics during six years of weed management systems in crop rotations on irrigated soil. Weed Sci 35:328-332

Norsworthy JK, Ward SM, Shaw DR, Llwellyn RS, Nichols RL, Webster TM, Bradley KW, Frisvold G, Powles SB, Burgos NR, Witt WW, Barrett M (2012) Reducing the risks of herbicide resistance: best management practices and recommendations. Weed Sci 60(Special Issue):31-62

Norsworthy JK, Griffin G, Griffin T, Bagavathianan, Gbur EE (2014) In-field movement of glyphosate-resistant Palmer amaranth (Amaranthus palmeri) and its impact on cotton lint yield: evidence supporting a zero-threshold strategy. Weed Sci 62:237-249

Nowak JP (1983) Obstacles to adoption of conservation tillage. J Soil Water Conserv 38:162-165

[NRCS] Natural Resources Conservation Service (2007) Soil Erosion on Cropland 2007. U.S. Department of Agriculture. http://www.nrcs.usda.gov/wps/portal/nrcs/detail/national/ technical/?cid=stelprdb1041887. Accessed August 11, 2014

Price AJ, Balkcom KS, Culpepper SA, Kelton JA, Nichols RL, Schomberg H (2011) Glyphosate-resistant Palmer amaranth: a threat to conservation tillage. J Soil Water Conserv 66:265275

Raper TB (2014) Managing Wheat for Top Yields and Grain Quality. UT Extension Pub. W321. http://www.utcrops.com/ wheat/Presentations/2015Raper_grain_conf_comp.pdf. Accessed December 12, 2014

Schweizer EE, Zimdahl RL (1984) Weed seed decline in irrigated soil after six years of continuous corn (Zea mays) and herbicides. Weed Sci 32:76-83

Sosnoskie LM, Webster TM, Grey TL, Culpepper AS (2014) Severed stems of Amaranthus palmeri are capable of regrowth and seed production in Gossypium hirsutum. Ann Appl Biol 165:147-154

Steckel LE, Sprague CL, Simmons FW, Bollero G (2003) Effect of shading on common waterhemp (Amaranthus rudis) growth and development. Weed Sci 51:898-903

Taylor SE, Oliver LR (1997) Sicklepod (Senna obtusifolia) seed production and viability as influenced by late-season postemergence herbicide applications. Weed Sci 45:497-501

[USDA] U.S. Department of Agriculture (2013) 2012 Tillage Systems. http://www.nass.usda.gov/Statistics_by_State/ Tennessee/Quick_Facts/tillage.pdf. Accessed June 17, 2014

VanGessel MJ (2001) Glyphosate-resistant horseweed in Delaware. Weed Sci 49:703-705

Received December 11, 2014, and approved March 17, 2015. 